\title{
Election 2015: new arguments for pharmacare
}

A fter decades of debate without federal action, it appears the conversation about universal public drug coverage is changing.

"The salience of this issue right now is arguably the highest it's ever been," says Steve Morgan, professor of health policy at the University of British Columbia in Vancouver. "Twenty years ago, it was difficult to point to other countries and say they're getting a better deal, but now the evidence is absolutely irrefutable."

Canada pays some of the highest prices in the world for prescription drugs, yet Canadians have relatively poor access to medicines. Ten percent can't afford to fill their prescriptions, compared to just 1 in 50 Britons, and out-ofpocket expenses vary widely depending on where a person lives and works.

\section{Slow progress}

Since the 1960s, litanies of politicians, health experts and economists have proposed universal pharmacare as a solution. Jean Chrétien's Liberals investigated, but never acted on, the notion in the '90s. Roy Romanow's 2002 report on the future of health care urged Ottawa to split drug costs with Canadians. Two years later, Paul Martin's Liberals committed to a national pharmaceutical strategy but progress stalled when Stephen Harper's Conservatives took power in 2006.

More recently, the Greens and New Democrats included pharmacare in their platforms for the coming federal election. Notably, New Democratic Party Leader Thomas Mulcair promised \$2.6 billion over the next four years to create a national public drug plan if he takes the Oct. 19 vote. The Liberals dismissed Mulcair's plan as economically unfeasible, while Conservatives have held the line that health care is a provincial responsibility.

\section{New evidence}

Pharmacare has "always been the bridesmaid" of health reform, largely

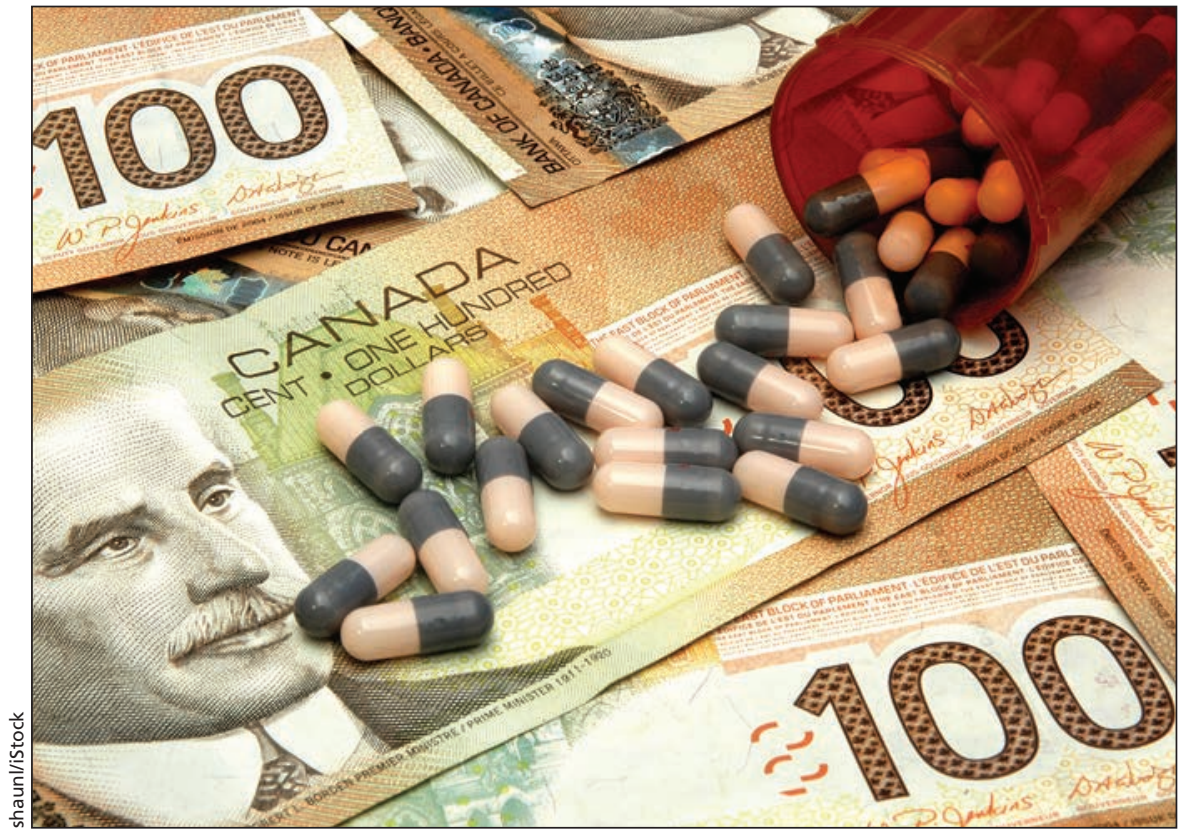

Experts say the economic case for universal pharmacare is stronger than ever, but will federal action follow?

because of concerns about the potential cost, says Morgan. But now, as Canada's drug spending per head is nearly double the average spent by peer nations, a stronger economic argument is emerging.

"There are very few cases in public policy where you can honestly say that doing the right thing is actually cheaper," Morgan explains. "This is one of those cases."

Morgan is the lead author of a recent $C M A J$ study that estimated universal pharmacare could slash prescription drug spending in Canada by $\$ 7.3$ billion annually. Patients and employers would reap most of these savings. In the best-case scenario, governments stand to save $\$ 2.9$ billion annually. At worst, costs to government could increase by $\$ 1$ billion, although these could be offset by long-term gains afforded by a healthier population.

Marc-André Gagnon, an assistant professor of health policy at Carleton University in Ottawa, says the federal government could also reallocate some $\$ 1.2$ billion in existing subsidies for employer-sponsored private drug plans. "This is massive public money we're already spending on very wasteful plans."

Private insurance accounts for $40 \%$ of drug spending in Canada. According to industry estimates, about a third of that money is wasted on expensive versions of drugs that have cheaper alternatives. Because employers mostly foot the bill for private insurance as a way of compensating workers, "coverage decisions are less about medical need and more about making employees happy," Gagnon explains. "When half your market starts with this position, it's impossible to negotiate a good price."

\section{Winners and losers}

Opponents of universal pharmacare argue that governments and private insurers could drive down prices by collaborating to buy drugs in bulk.

"If the provinces are on board, I don't see from a practical standpoint why the federal government needs to be involved," says Aaron Wurdick, federal director of the Canadian Taxpayers 
Federation, a not-for-profit that advocates for lower taxes and accountable government. "Maybe it would be nice symbolically, but to imply the provinces can't do anything without Ottawa's leadership is simply not true."

Wurdick says governments should balance the drive for lower costs against the potential impacts on industry. "If you start to impede the ability of companies to make a profit, you also run the risk of them doing less research in Canada."

Gagnon says this was partly why Canada beefed up patent protections for brand-name drugs in the " 80 s and, more recently, under the Canadian-European Economic Trade Agreement. But it's been years since drug companies upheld their end of the bargain to reinvest $10 \%$ of Canadian sales into local research and development, he says. "Now, we're just offering privileges for nothing."

Provinces can't hope to contain costs if the federal government is using its power over drug regulation and patents to artificially inflate prices, adds Morgan. "You need some way for Canada to hang together," and financial investment provides an incentive to keep costs low.

Bulk-purchasing agreements are a step in the right direction, says Gagnon, but they haven't achieved significant savings. For example, "the pan-Canadian Pharmaceutical Alliance managed to get $\$ 350$ million in rebates in 2014 , but that's just $1.5 \%$ of what we're paying for prescription drugs."

Regardless of how savings are achieved, "a better system at lower cost will threaten those who are benefiting from the status quo," says Morgan. But pharmaceutical and private insurance industries do stand to gain some benefits under a universal public plan.

For example, drug companies will get more streamlined access to the Canadian market. "They're going to get a national audience for new drugs fairly quickly without having to go through 13 different review processes," Morgan explains. That market may even expand as cost barriers are removed for the $10 \%$ of Canadians who currently can't afford to fill prescriptions. Governments may also contract private insurers to handle the day-to-day administration of a new public plan, notes
Morgan. "Provinces like Alberta and New Brunswick already do that."

\section{Agitating for change}

Provincial leaders are now pushing for a national plan. "The premiers have made it clear that they expect the federal parties to weigh in," Morgan says.

A July Angus Reid poll suggests the public expects the same: $91 \%$ of Canadians support the concept of a national pharmacare program that would provide universal access to prescription drugs.

The medical profession has also become "much more vocal and supportive," Morgan sats. On Oct. 1, the College of Family Physicians of Canada endorsed the Campaign for National Drug Coverage. And in August, the Canadian Medical Association voted in support of "equitable and comprehensive national pharmacare" at General Council.

"That's a game changer," Morgan says. "Twenty years ago, we didn't have that clinical leadership and now we do." — Lauren Vogel, CMAJ

CMAJ 2015. DOI:10.1503/cmaj.109-5178 